Review

\title{
Recent history and prospects of Plasma Research
}

\section{プラズマ研究の現状と将来}

\author{
Akira TONEGAWA \\ Department of Physics, School of Science, Tokai University, 1117 Kitakaname, Hiratsuka, Kanagawa, \\ 259-1292 Japan
}

TEL: x81-463-58-1211(EX.3710) FAX: x81-463-50-2013 e-mail: tone@keyaki.cc.u-tokai.ac.jp

( Received 15, December 2008 Accepted 23, March 2009 )

The history and prospects of plasma research in Japan are reviewed from the viewpoint of various research fields such as based on the nuclear fusion, plasma processing and space plasma. The previous and recent researches of plasma in Tokai University are also presented. Furthermore, many fundamentals are and /or applied researches of a sheet plasma which is a special type of strongly magnetized highly ionized slab plasma.

Keywords : History and Prospects, Plasma Research, Plasma group in Tokai University

\section{INTRODUCTION}

平成 20 年度は、プラズマ・核融合学会の前進である核 融合懇談会（初代会長：湯川秀樹先生）の発足から 50 周年を迎え、また、プラズマ・核融合学会自身が設立さ れてから 25 周年にあたる。発足から 50 周年を迎えた現 在のプラズマ研究は、主に 3 つの領域で研究が展開され ている。第 1 の領域は、国際協力の ITER (International Thermonuclear Experimental Reactor)のような未来のエネ ルギー源としての核融合、第 2 は、超 LSI 製造やフラッ トパネル等への先端技術としての応用を目的としたプラ ズマプロセス、そして第 3 の領域は、太陽フレアーや宇 宙ジェット等の自然のプラズマである。これらは全体と してプラズマ科学として体系化されつつある。この様な 状況は、核融合の研究が中心であった 20 年前と比較する と、予想をはるかに超えた展開になっている。

ここでは、プラズマ研究の铱引役となった核融合研究 の歴史をプラズマ核融合学会誌 Vo.1.84(2008 年)の特集号 を基に紹介する。1) 同時に、現在のプラズマ研究の状況 と将来の展望、更には東海大学のプラズマ研究グループ の歴史と研究内容について記載する。

\section{HISTORY OF FUSION RESEARCH IN JAPAN}

1955 年 8 月、「第 1 回原子力平和利用国際会議」がス
イスのジュネーブで開催され、インドのバーバー博士が、 「20 年以内に制御された形で核融合エネルギーを開放 する方策が見つけだされるであろう」と予言し、熱核融 合の平和利用という課題を指摘した。 3 年後の 1958 年、 第 2 回ジュネーブ会議には、日本から湯川秀樹先生と数 名の研究者が出席し、また同年、湯川秀樹先生が中心と なってプラズマ・核融合学会の前進である核融合反応懇 談会を設立された。これが日本における核融合研究の出 発点になったと言われている。この核融合反応懇談会の 参加研究者は、原子力委員の石川一郎先生、藤岡由夫先 生、有沢広已先生、湯川秀樹先生、さらには駒形作次先 生（原子力研究所（原研）の理事長 : 現在の原子力開発 機構）、嵯峨根遼吉先生、伏見康治先生（プラズマ研究所 初代所長)、中村誠太郎先生等、数名のメンバーから構成 されていた。その後、1961 年、名古屋大学の附置研究所 として、プラズマ研究所 (現在の核融合科学研究所 (National Institute of Fusion Science: nifs)の前進) が設立さ れ、日本における核融合の研究が本格的にスタートした。 1970 年代には、トカマク装置やへリカル装置等、本格的 な大型磁場核融合装置が建設された。同時に新しいプラ ズマ現象が発見され、不安定性やボーム拡散等により核 融合プラズマの閉じ込めに苦慮した時代でもあった。他 方、同年に原研で JT-60 の建設が始まり、1971 年には、 レーザー核融合による中性子の発生に成功し、日本の研 
究が世界の水準に並んだ時代であった。1980 年代には、 核融合科学研究所(nifs)の設立、ITER の政府間協定の開 始され、1990 年代は、JT-60 の高性能化や nifs の LHD 完 成がなされた。

2000 年になると、省庁統合により文部科学省が発足し、 科学技術・学術審查会は、「今後の我が国の核融合研究の あり方について」で、JT-60, LHD, レーザー, 材料照射を 4 本柱とする研究方針を定めた。また、2005 年フランス にはカデラシュに ITER の建設サイトが決定し、2018 年 のファーストプラズマの点火を目標に、 E U、日本、ロ シア、米国、中国、韓国、インドによる国際協力が本格 的にスタートした。また、核融合炉の実証には、反応に よって発生する $14 \mathrm{MeV}$ 中性子や高温プラズマに耐えら れる材料開発等の炉工学の研究が重要視され、2007 年に は ITER のブロードアプローチとして IFNIF(International Fusion Materials Irradiation Facility)が開始された。更に、 2008 年には JT-60 がシャットダウンし、 7 年後の 2015 年 を目標に、超伝導トカマクの JT-60SA として再スタート することが決定した。一方、LHD の研究では、高 $\beta$ 化、 長時間運転等の成果があり、今後、閉ダイバータ等の設 置、重水素実験により高性能化を図る予定になっている。

\section{RECENT RESEARCH IN PLASMA}

核融合分野以外の最近のプラズマ研究は、半導体製造 装置やフラットパネル等のプロセスプラズマ分野、太陽 フレアーや宇宙ジェット等の自然のプラズマの分野が広
がっている。

プラズマプロセス分野の研究は、約 50 年前から半導体 製造過程にプラズマを用いたドライプロセスが利用され て以来、小型コンピューターの普及や真空装置の高性能 化と低価格化により急速に広がっていった。そのため、 大学レベルの研究室でも小型の高真空装置を用いたプラ ズマ発生装置を設置し、プラズマの基礎研究が比較的容 易に実施できるようになった。また、プラズマ生成に、 直流放電以外の高周波放電、マイクロ波放電などが利用 され、小型で低価格な電源も開発され、多くの研究者が プラズマを容易に利用することが可能になった。現在で は、ボタンを押すだけで簡単にプラズマを生成すること ができる時代になっている。これらの技術は、その後、 半導体製造以外である液晶、プラズマディスプレイ、太 陽電池パネル等の表面改質や新素材生成へと応用が広が り、現在では医療やナノテクまで及んでいる。これらの プロセス分野のプラズマは、高温・高密度の核融合プラ ズマとは異なり、励起した中性粒子が混在した低温・低 密度の非平衡プラズマであり、使用するガスも水素やへ リウム等の希ガスからフッ化物や塩化物等の反応性ガス へ広がっており、プラズマ化学の分野へと広がっている。

一方、自然のプラズマの分野では、1980 年代になり、 人工衛星が各国で打ち上げられ、宇宙科学研究所の「よ うこう」やNASAの「ハッブル望遠鏡」等、宇宙からの 観測が活発になってきた。これらの観測データの一部は、 インターネット等の普及により情報開示されたため、多

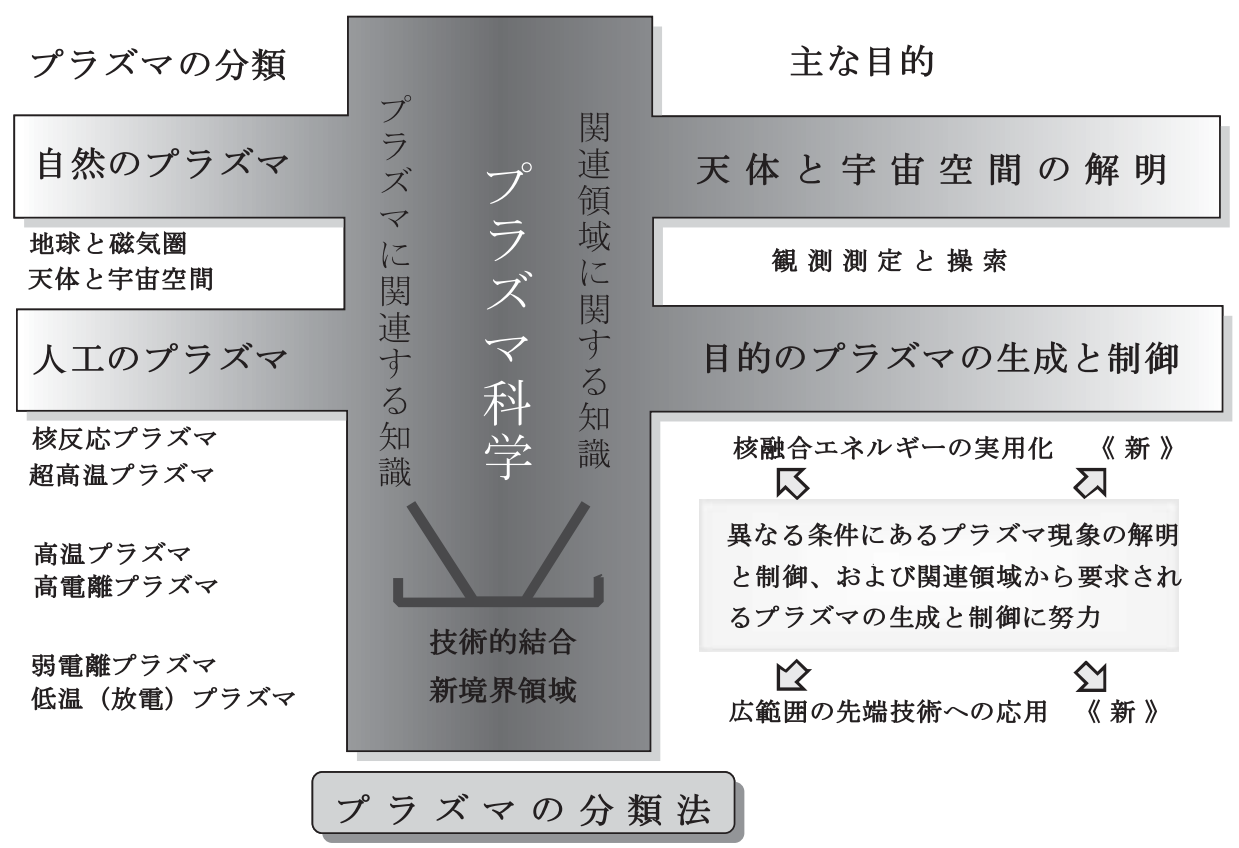

Fig.1 Clsssification of plasma research 
くの研究者によるデータ解析が可能になり、自然でのプ ラズマ現象の解明が急速に進んだ。また、核融合研究で 発達したシミュレーション技術は、自然のプラズマの現 象解明にも利用され、同時に、宇宙で発生している磁気 リコネクション現象や超新星爆発現象を、小型の核融合 装置やレーザー爆縮により模擬することが可能になり、 天体物理の研究者とプラズマの研究者の交流が益々、盛 んに行われている。

この様に発展している現在のプラズマの分野は、自然 のプラズマや人ロのプラズマに関する知識体系と、天 体・宇宙空間の解明と目的のプラズマの生成と制御等の 関連分野に関する知識体系に分類され、それらが技術的 に結合して新境界領域として広がっており、プラズマ科 学として体系化されつつある。このような分類法は、故 高山一男先生 (元プラズマ研究所所長、東海大学名誉教 授）によって 1983 年に提唱されている (Fig. 1 参照)。

\section{Prospects of plasma Research}

前章で記載した様に、プラズマ研究は急激に他の分野 との交流を深めプラズマ科学として体系化されている。

Fig.2 にプラズマ科学とプラズマ物理学との関係の例を 示す。この図からプラズマ科学は、電磁流体力学、運動 論、更には、原子・分子過程等の基礎的な学問に基づき、 理論・実験・シミュレーションの手法により、核融合プ ラズマを初めとする天体・宇宙プラズマ、プロセスプラ ズマ等の多くの研究分野と関連していることがわかる。 最近では、液体や固体表面でのプラズマ化学が関与する 低温・低密度のプラズマ、又は固体と光の相互作用が関 与寸る超短パススレーザーや強高度レーザーを用いた高 密度エネルギー科学、大規模なシミュレーションによる

\section{Plasma Science}

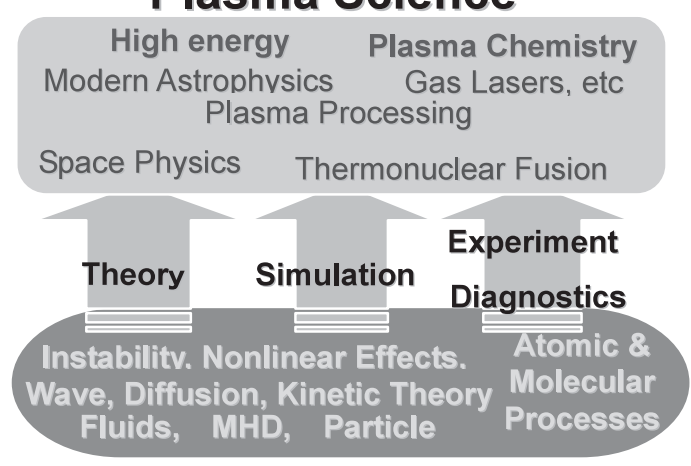

\section{Plasma Physics}

Fig.2 Relationship of the Plasma Physics and PlasmaScience.

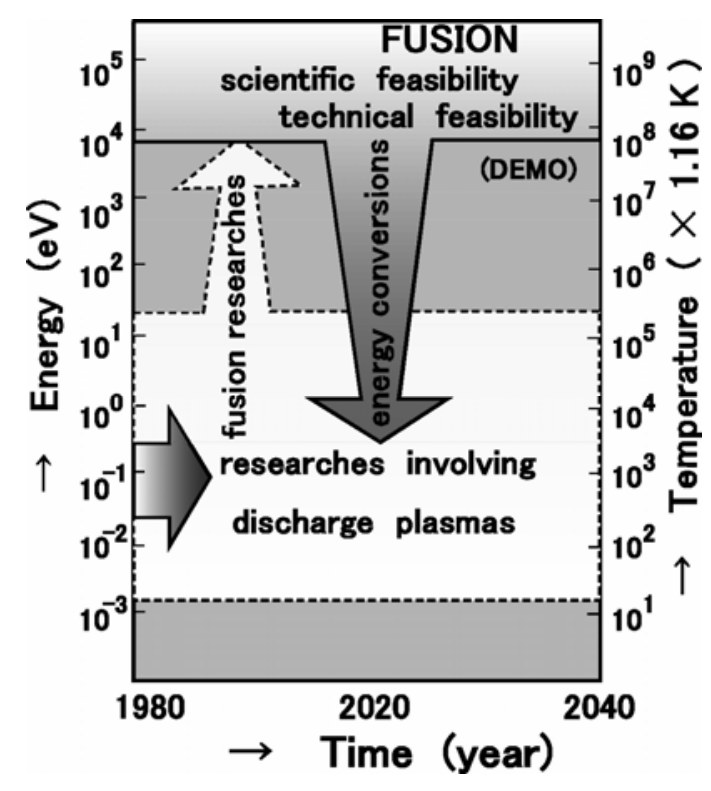

Fig.3 Relationship of the high temperature plasma and low temperature plasma

複雑系等も新しい分野として広がっている。特に、プラ ズマと液体との相互作用は、バイオテクノロジーに関係 する現象として、今後、基礎研究のみならず産業界への 応用も期待されている。

一方、核融合炉を実現するため、核融合プラズマの研 究は高温・高密度のプラズマ制御の研究のみならず、定 常に核融合プラズマを発生させ、炉心内からエネルギー を抽出する技術開発が不可欠となる。そのため、炉心プ ラズマと比較して低温状態の周辺プラズマの研究が必要 となり、プラズマや壁との相互作用の基礎研究が重要と なってきている (Fig.3 参照 : 高山一男先生提唱)。

\section{Recent History and Prospects of plasma Research in Tokai University Plasma Group} 現在の東海大学プラズマ研究グループは、プラズマ研 究所の所長を退官された高山一男先生が、1980 年、東海 大学の開発技術研究所（現在の総合科学技術研究所）の 教授に就任され、東海大学の教員を中心としたプラズマ 研究グループ (砂子克彦先生、宮下保先生、矢部栄二先 生、理学部物理学科の学生）を設立したことによりスタ ートした。1986 年にはプラズマ実験棟が建設され、東海 大学独自のシートプラズマや半導体用イオン源の開発を 行ない、プラズマプロセス分野を中心とした研究を進め ていた。シートプラズマとは、プラズマが厚さがイオン のラーモア半径の 2 倍程度まで圧縮した磁化プラズマで、 一種の極限状態の構造を有した境界プラズマである。本 
学で開発したシートプラズマは、高山先生がプラズマ研 究所で開発した TPD（Test Produced Directed current divice) プラズマ源をベースとした定常の板状プラズマで ある。

1987 年には、篠原元雄先生、谷川隆夫先生、南里憲三 先生、河村和孝先生がメンバーとして加わり、研究グル ープとして活発な研究活動がなされた。この間、イオン の旋回中心がプラズマ中心軸上にある極細のストリング プラズマや、小型 TPD プラズマ源によるプラズマ陰極を 有する長寿命イオン源の開発等が行われた。その後、1992 年には、小型シートプラズマ源を備えたオーロラプラズ マ生成診断装置が F 棟 1 階プラズマ第 2 実験室に設置さ れ、また、学内レーザー研究グループとの研究交流もあ り、各先生方の独自の研究が展開されていった。

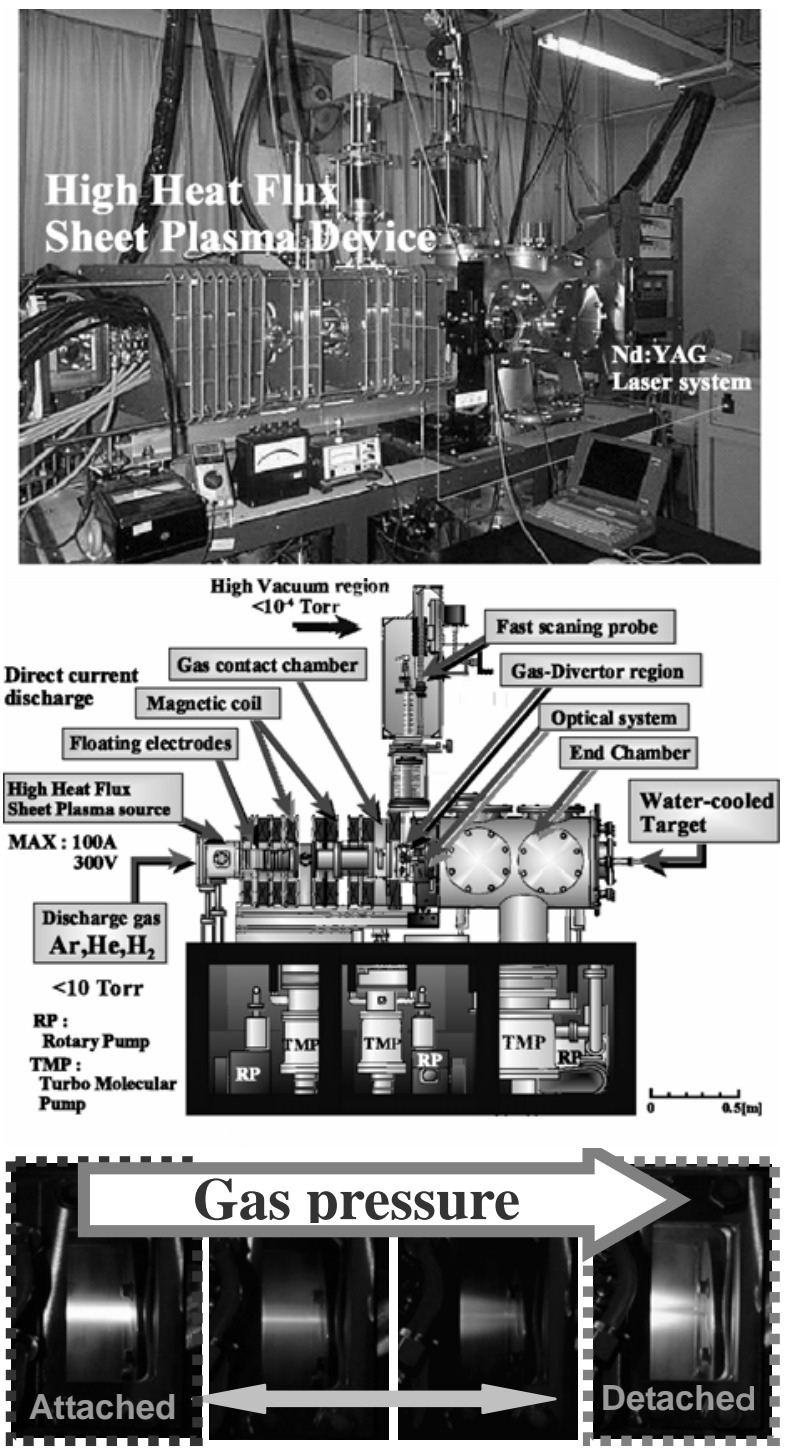

Fig.4 Schematic diagram of TPD-SheetIV and photograph of the recombing plasma.
1998 年には、核融合科学研究所との LHD 計画共同研 究（研究代表 : 河村和孝先生、1998-2003 年）や TPD 共 同研究がスタートし、本学プラズマ研究グループの研究 課題はプラズマプロセス分野から核融合分野へと大きく 転換された。この間、渋谷猛久先生（現東海大学工学部 教授）が新たにメンバーに加わった。それ以降、3回に わたる LHD 計画共同研究の実施や東海大学内の 17 号館 研究プロジェクトの推進により、核融合分野とプラズマ プロセス分野を軸とした研究を展開してきた。2002 年度 には、オーロラプラズマ生成診断装置の大電流化を行い、 放電電流 $100 \mathrm{~A}$ の水素のシートプラズマを生成し、核融 合ダイバータの模擬可能な高熱流シートプラズマ発生装 置（TPD-SheetIV）の開発に成功した。

Fig. 4 に TPD-SheetIV の装置概念図と核融合ダイバー 夕部を模擬した再結合プラズマの写真を示す。現在では、 TPD-SheetIV を用いた核融合周辺プラズマの基礎研究と シートプラズマを用いた応用研究等を実施している。具 体的な研究課題は以下のようである。

（1）シートプラズマを用い核融合ダイバータ模擬と

再結合プラズマの基礎研究

（2）シートプラズマを用いたイオンサイクロトロン 共鳴加熱とその応用研究

(3) 質量分析器や分光等のプラズマ診断の開発研究

\section{CONCLUSION}

核融合研究を中心として発展してきたプラズマの研 究分野は、今後、ITER 等の大型装置を中心とした国際的 な核融合研究、新しいプラズマ現象に関する基礎研究と 先端技術に関連する応用研究、更には、天体・宇宙やバ イオテクノロジー等への異種分野との境界領域研究へと 多様化・拡大していくと考えられる。また、本学のプラ ズマ研究グループでは、シートプラズマによる核融合周 辺プラズマの基礎研究とその応用研究を推進し、特色あ るプラズマ研究を遂行する。

\section{ACKNOWLEDGEMENTS}

本内容は、故高山一男先生を初め、多くの東海大学プ ラズマ研究グループの先生方と卒業生の皆様の研究活動 に基づいたものであり、本投稿にあたり心から感謝いた します。

\section{REFERENCES}

1. S.Matuda, and S.Takamura, Journal of Plasma and Fusion Research, Vo.l.84,(2008),pp.1-100. 